\title{
PEMBERDAYAAN BAHASA INDONESIA DALAM USAHA PENGURANGAN BENTUK CAMPUR KODE BAHASA JEPANG KE DALAM BAHASA INDONESIA
}

\author{
Mhd. Pujiono \\ Fakultas Ilmu Budaya, Universitas Sumatera Utara \\ Pos-el: mpoejiono@yahoo.co.id
}

\begin{abstract}
Abstrak
Penelitian ini membahas tentang campur kode yang terjadi dalam masyarakat bilingual seperti di kalangan warga keturunan Jepang Indonesia di kota Medan. Campur kode bahasa Jepang di dalam bahasa Indonesia tersebut sangat sulit dihilangkan. Hal ini disebabkan karena warga keturunan memiliki dua bahasa ibu yaitu bahasa Indonesia dan bahasa Jepang. Metode yang digunakan dalam penelitian ini adalah metode kualiatif deskriptif. Teknik pengumpulan data menggunakan teknik angket dan catat. Untuk mengetahui seberapa besar campur kode yang terjadi di kalangan warga keturunan Indonesia-Jepang, diperlukan sebanyak 20 orang sebagai informan warga keturunan Indonesia-Jepang. Hasil yang diperoleh dari angket yang dibagikan, campur kode bentuk leksikal sebanyak 75\%, campur kode bentuk frasa sebanyak 8,3\% dan campur kode bentuk klausa sebanyak $16,7 \%$. Untuk mengurangi terjadinya campur kode di kalangan warga keturunan Indonesia-Jepang tersebut, diperlukan suatu pemberdayaan bahasa Indonesia. Salah satu bentuk pemberdayaan tersebut adalah menanamkan rasa prestise (bangga) dan loyalitas terhadap penggunaan bahasa Indonesia di kalangan warga keturunan Jepang Indonesia. Dengan loyalitas itu, bahasa Indonesia akan diwariskan dari generasi ke generasi. Selain itu, menjadikan bahasa Indonesia menjadi bahasa pengantar di lingkungan warga keturunan Indonesia-Jepang dan juga dalam upacara-upacara yang berhubungan dengan budaya.
\end{abstract}

Kata kunci : campur kode, warga keturunan, pemberdayaan

\begin{abstract}
This research elaborates the code mixing occurs in bilingual society of Japanese Indonesian descendents in Medan city. Japanese code mixing in bahasa Indonesia is difficult to avoid. This is due to the situation where the Japanese Indonesian descendants have two mother tongues: Indonesian and Japanese. The method used in this research was descriptive qualitative. The technique of collecting data used was questionnaire and note taking. In order to reveal the sheer of code mixing occurs amongst Indonesian Japanese descendants, 20 informants were required. The result obtained from the distributed questionnaires reveals that lexical code mixing is $75 \%$, phrase code mixing is $8,3 \%$ and clause code mixing is $16,7 \%$. In order to reduce the code mixing amongst the Indonesian-Japanese descendants, the empowerment of bahasa Indonesia is urgently required. One of the empowerments is by instilling the prestige and allegiance toward the use of bahasa Indonesia amongst Indonesian Japanese descendants. With the allegiance, bahasa Indonesia will eventually bestowed upon generation to generation. Besides that, utilizing bahasa Indonesia to become the medium of instruction within the environment of Indonesian Japanese descendants and in cultural ceremonies will also assist to empower bahasa Indonesia within the Indonesian Japanese descendants society in Medan.
\end{abstract}

Key words: code mixing, Japanese descendants, empowerment 


\section{PENDAHULUAN}

Komunikasi digunakan untuk menyampaikan pesan atau mengadakan komunikasi di antara pembicara kepada penerima pesan tersebut melalu bahasa. Bahasa adalah system lambang bunyi yang arbitrer yang dipergunakan oleh para anggota suatu masyarakat untuk bekerja sama, berinteraksi dan mengidentifikasikan diri (Kridalaksana, 2001:21). Dalam pengertian ini dapat dipahami bahwa bahasa sebagai alat interaksi manusia. Interaksi yang dimaksud yaitu antara manusia satu dengan manusia lainnya secara individu maupun secara kelompok di dalam masyarakat.

Interaksi yang ada di dalam masyarakat, terjadi karena adanya kontak bahasa. Kontak bahasa (language contact) merupakan pengaruh unsur atau bahasa terhadap bahasa lain, baik secara langsung maupun tidak langsung (Ridjin, 1981:13). Lebih lagi proses kontak bahasa sangat didukung oleh faktor dari dalam individu penutur bahasa tersebut, misalnya kemampuan atau penguasaan individu penutur dalam berbahasa lebih dari satu. Hal ini sejalan dengan anggapan Kridalaksana (2001: 120) bahwa kontak bahasa merupakan gejala saling mempengaruhi antara berbagai bahasa karena penuturnya saling bertemu dan di dalamnya konsep seperti kedwibahasaan, pencampuaran dan peralihan bahasa. Artinya tidak hanya faktor individu penutur saja, melain terdapat pula pengaruh dari lingkungan penutur.

Keterkaitan dengan lingungan dalam hal ini adalah masyarakat dimana penutur tinggal dan beraktifitas menghasilkan salah satu fenomena yang disebut kedwibahasaan. Kedwibahasaan atau istilah dalam bahasa Inggrisnya disebut bilingualism, berasal dari dwibahasa. Hal ini berkenaan dengan persentuhan dalam bahasa secara sosiolinguistik, kedwibahasaan diartikan sebagai penggunaan dalam bahasa bergantian oleh penutur dalam pergaulannya dengan orang lain (Mackey, 1968 :12, Fishman, 1972: 73).
Penggunaan dua bahasa secara bergantian oleh penutur akan mengakibatkan terjadinya campur kode. Hal ini terjadi di dalam warga keturunan Indonesia-Jepang di kota Medan. Campur kode yang dimaksud adalah campur bahasa yang terjadi antara bahasa Indonesia dan bahasa Jepang.

Campur kode dalam bahasa Inggris disebut Code-Mixing, merupakan penggunaan satuan bahasa dari satu bahasa ke bahasa lain untuk memperluas gaya bahasa atau ragam bahasa, termasuk di dalamnya pemakaian kata, klausa, idiom sapaan dan sebagainya (Kridalaksana, 2001 : 35). Menurut Suwito (1983 : 7880) wujud campur kode dapat dibedakan menjadi lima. (1) Penyisipan unsur-unsur berwujud kata, (2) penyisipan unsur-unsur berwujud frasa (3) penyisipan unsur-unsur berwujud klausa, (4) penyisipan unsur-unsur pengulangan kata, (5) penyisipan unsur-unsur berwujud idiom atau ungkapan. Penggunaan campur kode yang terjadi di dalam warga keturunan Indonesia-Jepang apabila terlalu sering akan menimbulkan gangguan (interferensi) dalam berbahasa.

Interferensi adalah pengguanaan unsur bahasa lain oleh bahasawan yang bilingual secara individual dalam suatu bahasa, ciri-ciri bahasa lain itu masih ketara (Kridalaksana, 2001: 84). Warga keturunan Indonesia-Jepang merupakan masyarakat bilingual yang sering menggunakan dua bahasa, yaitu bahasa Indonesia dan bahasa Jepang. Apabila kedua bahasa tersebut digunakan secara bersamaan, atau bahasa Jepang lebih sering digunakan di dalam percakapan sehari-hari oleh warga keturunan Indonesia-Jepang, tanpa disadari akan mengurangi rasa cinta terhadap bahasa Indonesia. Pengguanaan campur kode (campur bahasa) tersebut dapat berupa kata, kalimat dan sebagainya. Informan yang digunakan dalam penelitian ini sebanyak 20 orang warga keturunan Indonesia-Jepang di kota Medan. Untuk mengetahui bentuk campur kode tersebut, maka dibagikan angket terhadap warga 
keturunan Indonesia-Jepang tersebut. Selain itu, untuk mengurangi bentuk campur kode yang dilakukan warga keturunan IndonesiaJepang tersebut, perlu dilakukan pemberdayaan bahasa Indonesia. Hal ini dilakukan agar warga keturunan Indonesia-Jepang tersebut dapat loyal menggunakan bahasa Indonesia di dalam masyarakat.

Dari uraian di atas, maka perlu dirumuskan beberapa tujuan penelitian ini antara lain sebagai berikut :

1. Mendeskripsikan wujud campur kode secara umum.

2. Mendeskripsikan wujud campur kode paling dominan yang digunakan warga keturunan Indonesia-Jepang di kota Medan.

3. Menjelaskan permberdayaan bahasa Indonesia untuk mengurangi campur kode.

Berdasarkan uraian mengenai latar belakang, permasalahan, dan tujuan penelitian di atas, maka penelitian ini memiliki dua manfaat. yaitu manfaat teoritis dan manfaat praktis. Manfaat Teoritis dari penelitian ini yaitu dapat mengetahui bentuk campur kode bahasa Jepang ke dalam bahasa Indonesia di kalangan warga keturunan Indonesia-Jepang. Kemudian manfaat praktis dari penelitian ini yaitu memberikan sumbangan pemikiran dan sebagai rujukan bagi peneliti lain untuk mengembangkan penulisan tentang linguistik secara umum, terutama dalam hal campur kode di dalam berbahasa. Selain itu, penelitian ini juga bermanfaat dalam pemberdayaan bahasa Indonesia untuk mengurangi campur kode dari berbagai bahasa asing.

\section{TEORI DAN METODE}

Penelitian ini menggunakan metode kualitatif deskriptif. Menurut Moleong (2000:55) pendekatan kualitatif menekankan pada proses, maka penelusuran data dan informasi secara diakronik akan dilakukan untuk mengetahui dan memahami secara runtun dan leng- kap. Mengingat esensi metode kualitatif dalam memandang masyarakat itu sebagai subjek, berdasarkan pandangan masyarakat itu sendiri, sehingga data yang didapat benar-benar seperti adanya.

Dalam penelitian ini digunakan data dan sumber data. Sumber data dalam penelitian ini adalah informan sebanyak 20 orang warga keturunan Indonesia-Jepang yang tinggal di kawasan kota Medan. Data yang digunakan dalam penelitian ini adalah hasil angket yang dibagikan kepada informan penlitian. Dari angket yang diisi para informan yang berkaitan dengan data pribadi seperti nama dan jenis kelamin tidak dituliskan di dalam penyajian data tetapi menggunakan urutan angka romawi.

Teknik yang digunakan dalam pengumpulan data adalah teknik angket dan catat. Teknik membagi Angket / kuesioner adalah teknik pengumpulan data yang dilakukan dengan cara memberikan seperangkat pertanyaan kepada orang lain yang dijadikan responden untuk dijawabnya (Sugiono, 2007:163). Lalu teknik catat menurut Sudaryanto (1993:135) bertujuan untuk mencatat data yang diperoleh dari observasi. Data yang diperoleh dicatat pada kartu data atau pencatatan dapat memanfaatkan komputer.

Setelah dilakukan pengumpulan data, selanjutnya memasuki tahap analisis data. Menurut Miles, Huberman dan Saldana (2014: 14), tahapan dalam menganalisis data yaitu reduksi data, penyajian data dan penarikan kesimpulan.

Teori campur kode yang digunakan untuk menganalisis dalam penelitian ini adalah menurut Suwito (1983). Menurut Suwito (1983 : 78-80) wujud campur kode dapat dibedakan menjadi lima. (1) Penyisipan unsur-unsur berwujud kata, (2) penyisipan unsur-unsur berwujud frasa (3) penyisipan unsur-unsur berwujud klausa, (4) penyisipan unsur-unsur pengulangan kata, (5) penyisipan unsur-unsur berwujud idiom atau ungkapan. 
Metode yang digunakan dalam penyajian hasil analisis data dalam penelitian ini adalah metode metode informal. Menurut Sudaryanto (1993:145) metode penyajian informal adalah perumusan dengan kata-kata biasa, maksudnya menjelaskan analisis dengan menggunakan kata-kata dan kalimat dalam bentuk wacana.

Metode penghitungan analisis data sebagai pendukung metode analisis wujud campur kode menggunakan metode yang disarankan oleh Halliday dan Hasan (1976:201) Seperti Berikut :

\section{Contoh :}

Jenis campur kode di bidang leksikal berjumlah 450 kali dari 600 total jumlah pertanyaan campur kode yang diberikan pada 20 orang informan. Oleh karena itu perhitungan persentasinya sebagai berikut :

$$
\frac{450}{600} \times 100=75 \%
$$

\section{HASIL DAN PEMBAHASAN}

Pada penelitian ini hasil yang dicapai antara lain wujud campur kode yang paling dominan yang digunakan warga keturunan Indonesia-Jepang di kota Medan dan permberdayaan bahasa Indonesia untuk mengurangi campur kode tersebut.

Data hasil pengisian angket dari informan, masing-masing informan diberikan 30 pertanyaan sehingga dari 20 orang informan terdapat total 600 butir jawaban yang berisi wujud campur kode leksikal (kata), frasa dan klausa sesuai dengan pendapat Suwito (1983). Wujud campun kode yang ditemukan dalam penelitian ini berupa campur kode dalam leksikal, frasa dan klausa. Presentase jumlah campur kode yang terjadi dilihat dari hasil angket yang dibagikan yaitu, campur kode bentuk leksikal sebanyak 75\%, campur kode bentuk frasa sebanyak 8,3\% dan campur kode bentuk klausa sebanyak $16,7 \%$.
Berikut contoh tabel data hasil angket dalam penelitian ini.

Tabel 1. Jenis, Jumlah dan Persentase Jumlah Wujud Campur Kode dalam Kalangan Warga Keturunan Indonesia-Jepang di Kota Medan

\begin{tabular}{|c|c|c|c|c|c|}
\hline \multirow{2}{*}{ Informan } & \multirow{2}{*}{ Umur } & \multirow{2}{*}{ Pekerjaan } & \multicolumn{3}{|c|}{ Wujud Campur Kode } \\
\hline & & & Leksikal & Frasa & Klausa \\
\hline I & 46 & Wiraswasta & 15 & 3 & 2 \\
\hline II & 52 & Wiraswasta & 25 & 3 & 2 \\
\hline III & 42 & Wiraswasta & 20 & 1 & 2 \\
\hline IV & 47 & Wiraswasta & 22 & 1 & 2 \\
\hline $\mathrm{V}$ & 19 & Mahasiswa & 8 & 1 & 1 \\
\hline $\mathrm{VI}$ & 37 & Wiraswasta & 12 & 2 & 2 \\
\hline VII & 20 & Mahasiswa & 10 & 1 & 1 \\
\hline VIII & 39 & Wiraswasta & 12 & 2 & 2 \\
\hline IX & 43 & Wiraswasta & 17 & 2 & 2 \\
\hline $\bar{X}$ & 44 & Wiraswasta & 18 & 2 & 6 \\
\hline$\overline{\mathrm{XI}}$ & 44 & Wiraswasta & 20 & 2 & 3 \\
\hline XII & 47 & Wiraswasta & 22 & 2 & 4 \\
\hline XIII & 57 & Wiraswasta & 39 & 2 & 10 \\
\hline XIV & 63 & wiraswasta & 41 & 5 & 12 \\
\hline $\mathrm{XV}$ & 61 & Wiraswasta & 42 & 5 & 12 \\
\hline XVI & 59 & Wiraswasta & 39 & 5 & 8 \\
\hline XVII & 55 & Mahasiswa & 39 & 3 & 8 \\
\hline XVIII & 58 & Wiraswasta & 19 & 2 & 10 \\
\hline XIX & 60 & Wiraswasta & 23 & 5 & 10 \\
\hline$X X$ & 21 & Mahasiswa & 7 & 1 & 1 \\
\hline \multicolumn{3}{|c|}{ Jumlah campur kode } & 450 & 50 & 100 \\
\hline \multicolumn{3}{|c|}{$\begin{array}{c}\text { Presentase campur kode } \\
\text { Jumlah Campur kode X 100 } \\
\text { Total Jumlah campur kode (600) }\end{array}$} & $75 \%$ & $8,3 \%$ & $16,7 \%$ \\
\hline
\end{tabular}

Dari data yang diperoleh wujud campur kode berupa penyisipan unsur-unsur berwujud leksikal sangat dominan sebanyak 450 kata atau $75 \%$ dari 20 orang informan yang menjawab di dalam angket. Salah satu contoh penyisipan unsur-unsur berwujud kata terdapat dalam beberapa macam kata, yaitu :

1. Penggunaan kata nama keluarga

Contoh :

penggunaan kata

$\begin{array}{ll}\text { okaasan } & \text { 'ibu', } \\ \text { otousan } & \text { 'ayah', } \\ \text { obasan } & \text { 'bibi', } \\ \text { imouto-san } & \text { 'adik(Pr)' } \\ \text { dan sebagainya. } & \end{array}$


Kata-kata ini digunakan di lingkungan keluarga untuk menggantikan panggilan anggota keluarga. Misalnya pada tuturan "otousan sudah pulang?," "okaasan masak apa hari ini?" dan sebagainya.

2. Penggunaan kata pronomina (kata ganti orang)

Contoh :

penggunaan kata

watashi 'saya'
anata 'kamu',
$\sim \sim$ san 'saudara'
dan sebagainya.

dan sebagainya.

Kata-kata ini digunakan sehari-hari untuk menyebutkan kata ganti orang untuk diri sendiri maupun orang lain. Misalnya pada tuturan, "hiro-san cepat sini!" , "watashi juga mau.." dan sebagainya.

3. Penggunaan Kata benda (Nomina)

Contoh :

pada kata

Gohan 'nasi',

koucha 'teh',

mizu 'air',

juusu 'jus'

dan sebagainya.

Tuturan sehari-hari penggunaan kata benda diatas milsanya, "hiro-san tolong ambilkan mizu segelas!" dan "gohan-nya sudah masak?" dan sebagainya.

4. Penggunaan kata keterangan waktu

Contoh :

Ashita 'besok',

Kinou 'kemarin',

Raishuu 'minggu depan'

dan sebagainya.

Kata-kata keterangan waktu diatas sering wujud dalam tuturan seperti "ashita jadi pergi?", "raishuu mereka datang." Dan sebagainya.

Selanjutnya wujud campur kode berupa penyisipan unsur-unsur berwujud frasa adalah yang paling sedikit yaitu sebanyak 50 frasa atau $8,3 \%$ dari 20 orang informan yang mengisi angket. Contoh dari penyisipan unsur-unsur berwujud frasa tersebut yaitu

pengguanan frasa

onaka ga sukimashita
hara ga tachimashita
dan sebagainya.

Frasa ini wujud dalam tuturan seperti "okaasan, Gohan-nya sudah masak? Onaka tsukimashitayo!", "lihat kelakuan anak ini kadang-kadang buat hara ga tachimashita pak." dan sebagainya.

Wujud campur kode berupa penyisipan unsur-unsur berwujud klausa sebanyak 100 klausa atau 16,7 \% dari 20 orang informan yang mengisi angket. Jumlah ini sedikit lebih banyak dari pada jumlah penyisipan unsur pada frasa. Contoh penggunaan klausa sebagai berikut :

(1) Di sini nani o shiteimasuka

Di sini sedang melakukan apa?

(2) Di rumah chahan wo tsukurimashita.

Di rumah sudah membuat nasi goreng, dan sebagainya.

(3) Hari ini doko e iku no?

Hari ini mau pergi kemana?

(4) Kalau itu sawatteha dame yo!

Kalau itu tidak boleh dipegang ya!

Selain wujud campur kode pada klausa seperti diatas, hasil analisis data juga menemukan beberapa bentuk campur kode frasa dan kalusa yang berupa pengulangan serta idiom dalam bahasa Jepang. Hal ini juga sesuai dengan pendapat Suwito (1983) bahwa campur kode juga dapat terjadi akibat penyisipan unsur-unsur pengulangan kata dan penyisipan unsur-unsur berwujud idiom atau ungkapan. Berikut beberapa contoh frasa dan klausa tersebut.

(5) Dia itu memang warukuchi

Dia itu 'mulutnya buruk'

(6) hara ga tachimashita

'Perut tegak' 
(7) Hai, apa kabar? Ogenki desuka.

Hai, Apa kabar? Apa kabar?

Pada klausa (5) dan frasa (6) terdapat idiom warukuchi dan hara ga tachimashita. warukuchi jika diartikan secara harfiah bermakna 'mulut buruk' namun makna idiomatiknya adalah 'perkataannya buruk.' Lalu hara ga tachimashita jika diartikan secara harfiah bermakna 'perutnya tegak' namun makna idiomatiknya adalah 'marah.' Pada klausa (7) terjadi pengulangan makna 'apa kabar' karena ogenki desuka juga berarti 'apa kabar' dalam bahasa Jepang.

Dengan melihat hasil wujud campur kode yang terjadi di kalangan warga keturunan Indonesia-Jepang di Kota Medan, secara tanpa disadari campur kode yang sering diterjadi pada informan yang umurnya berkisar 40 hingga 63 tahun. Hal ini menunjukkan bahwa warga keturunan Indonesia-Jepang masih sering mencampurkan antara bahasa Indonesia dan bahasa Jepang di dalam kehidupan seharihari. Untuk mengurangi wujud campur kode ini maka perlu dilakukan upaya pemberdayaan bahasa Indonesia di kalangan warga keturunan Indonesia-Jepang tersebut.

Dalam hal ini yang diperlukan adalah kiat pemberdayaan bahasa Indonesia di kalangan warga keturunan Indonesia-Jepang di kota Medan dengan cara pembudayaan dan memberikan peluang serta kesempatan bagi pengguna dalam memberdayakan bahasa Indonesia secara kreatif dan inovatif. Dengan kreativitas dan inovasi tersebut pemberdayaan bahasa Indonesia dapat dikembangkan dalam pembangunan peradaban komunikasi bangsa Indonesia. Kiat-kiat berikut layak dipertimbangkan dalam pemberdayaan tersebut (Moeliono, 1985 :60). Berikut adalah beberapa macam hal yang dapat digunakan dalam pemberdayaan bahasa Indonesia melalui pembudayaan bahasa, yaitu :
1. Pembudayaan Penggunaan Bahasa Indonesia yang Baik dan Benar

Sejalan dengan bahasa adalah seperangkat kebiasaan (language is a set of habits), penggunaan bahasa juga merupakan kebiasaan yang terjadi masyarakat pengguna bahasa. Karena itu, kebiasaaan itu perlu, bahkan harus, mendapatkan perhatian dari para penutur dan mitra tutur. Kebiasaan yang baik tentu menjadi harapan semua komunitas yang peduli dengan nilai-nilai budaya yang beradab.

Berdasarkan alur pikir tersebut, pembiasaan berbahasa Indonesia dengan baik dan benar merupakan salah satu trategi pembudayan. Pembisaan penggunaan bahasa Indonesia memiliki posisi strategis dalam pembangunan budaya berbahasa Indonesia, yang pada gilirannya menjadi salah satu pilar pembangunan peradaban komunikasi bangsa.

Pembiasaan bahasa indonesia ini juga perlu dilakukan di kalangan warga keturunan Indonesia-Jepang sebagai upaya pembangunan budaya berbahasa Indonesia dengan baik dan benar.

2. Pembudayaan Penggunaan Bahasa Indonesia dengan Percaya Diri

Penggunaan bahasa Indonesia dengan percaya diri perlu menjadi kebiasaan. Percaya diri itu mengarah pada dua hal, yakni (1) keyakinan akan kehandalan bahasa Indonesia sebahagai alat komunikasi bangsa, yang memang harus dijunjung tinggi dengan percaya diri, dan (2) tanggung jawab penutur atas substansi yang dituturkan.

Percaya diri pada butir (1) mengarahkan penutur pada pilihan unsur bahasa yang digunakan di antara dua pilihan: unsur bahasa Indonesia atau unsur bahasa lain, termasuk bahasa asing. Dengan percaya diri bahwa bahasa Indonesia itu handal, maka pilihan unsur akan jatuh pada bahasa Indonesia. Dalam bertutur, penutur yang demikian itu akan mengutamakan penggunaan unsur bahasa Indonesia darpada unsur bahasa lain. 
Percaya diri pada butir (2) mengarahkan penutur pada pilihan unsur penanda penanggung jawab yang berupa pronomin persona. Dalam perkembangan akhir-akhir ini, ada kerancuan-kerancuan dalam pemilihan dan penggunaan pronominal persona sebagai penanda tanggung jawab penutur.

Pelarian tanggung jawab dengan tidak menggunakan pronominal persona, dapat pula ditemukan. Tuturan yang berorientasi keadaan dapat digunakan oleh penutur untuk menghindari dirinya sebagai pihak yang bertanggung jawab.

Dalam kalangan warga keturunan Indonesia-Jepang, fenomena penggunaan campur kode leksikal yang didalamnya juga terdapat pronomina dalam bahasa Jepang merupakan salah satu gambaran ketidak yakinan akan kehandalan bahasa Indonesia sebahagai alat komunikasi bangsa yang harus dijunjung tinggi dan kurangnya tanggung jawab penutur atas substansi yang dituturkan.

3. Pembudayaan Penggunaan Bahasa Indonesia yang Efektif

Penggunaan bahasa Indonesia yang tidak efektif terjadi pada dua kelompok penutur: penutur kalangan terpelajar dan penutur kalangan kurang terpelajar.

Hingga dapat dimengerti bahwa penggunaan bahasa yang tidak efektif terjadi pada kalangan kurang terpelajar karena kapasitas dan intelektualnya tidak memenuhi syarat untuk menggunakan bahasa Indonesia yang efektif. Sebaliknya, penutur kalangan terpelajar seharusnya memenuhi syarat kapasitas dan kapabilitas untuk menggunakan bahasa Indonesia yang efektif, karena itu pentingnya pembudayaan bahasa Indoensia dalam dunia pendidikan sangat diperlukan.

4. Pembudayaan Penggunaan Bahasa Indonesia yang Loyal

Dari segi loyalitas, semakin sering menggunakan bahasa Indonesia sebagai bahasa ibu, rasa mencintai dan memiliki bahasa Indonesia akan semakin kuat. Dengan semakin kuat rasa memiliki bahasa ibu yaitu bahasa Indonesia, maka akan mengurangi penggunaan bahasa lain khususnya bahasa asing. Selain itu di dalam pertemuan-pertemuan yang bernuansa formal dan tidak formal sebaiknya menunjukkan sikap loyal dalam berbahasa dengan mengguanakan bahasa Indonesia yang baik dan benar.

Dalam kalangan warga keturunan Indonesia-Jepang, apabila dilaksanakan pertemuapertemuan antara sesama warga keturunan Indonesia-Jepang masih sering digunakan bahasa Jepang dan interaksi yang terjadi antar sesama warga keturunan juga mencampurkan bahasa Indonesia dengan bahasa Jepang. karena itu upaya membiasakan untuk menggunakan bahasa Indonesia sangat diperlukan sebagai bentuk loyalitas dalam berbahasa Indonesia.

5. Pembudayaan bangga pada bahasa Indonesia

Pembudayaan yang diperlukan Untuk mengurangi terjadinya campur kode di kalangan warga keturunan Indonesia-Jepang salah satunya adalah dengan menanamkan rasa prestise (bangga) dan loyalitas terhadap penggunaan bahasa Indonesia di kalangan warga keturunan Indonesia-Jepang. Dengan loyalitas itu, bahasa Indonesia akan diwariskan dari generasi ke generasi. Selain itu, menjadikan bahasa Indonesia menjadi bahasa pengantar di lingkungan warga keturunan Indonesia-Jepang dan juga dalam upacara-upacara yang berhubungan dengan budaya. Menanamkan rasa bangga pada bahasa Indonesia dikalangan warga-warga keturunan, akan menjadikan warga keturunan lebih sering menggunakan bahasa Indonesia dari pada bahasa asing dalam kehidupan sehari-hari.

Pembudayaan rasa bangga terhadap bahasa Indonesia dapat dilakukan dengan banyak cara. Tidak hanya usaha apa yang harus dilakukan warga keturunan Indonesia-Jepang sendiri, namun juga harus diikuti dengan usaha 
pemerintah dalam memberikan jalan untuk terwujudnya hal tersebut. Misalnya dari sektor pendidikan, kurikulum dalam pendidikan di Indonesia sebaiknya menekankan rasa cinta dan bangga pada bahasa Indonesia. Sejauh ini kurikulum 2013 dengan penghapusan mata pelajaran bahasa Inggris dan bahasa asing lainnya di sekolah dasar memang dapat menjadi jawaban sementara. Di sisi lain jika saat ini masih terdapat argumen di masyarakat yang menyatakan bahwa penguasaan bahasa Inggris mempengaruhi percepatan penguasaan IPTEK pada generasi muda, maka dari sini untuk mengakomodir kekhawatiran tersebut pemerintah perlu mempertimbangkan beberapa hal, misalnya dengan memperbanyak ruang untuk menerjemahkan karya-karya yang sangat penting dalam bahasa asing ke dalam bahasa Indonesia. Kemudian memaksimalkan fungsi guru dalam pendidikan juga menjadi alternatif. Sebagai pendidik penanaman karakter dan pembentukan sikap mental dan sikap bahasa yang baik adalah tugas utama guru di sekolah. Guru sebagai model bagi siswa tentunya harus tampil menjadi model terbaik dalam menggunakan Bahasa Indonesia.

Cara lain yang dapat ditempuh adalah memaksimalkan fungsi UKBI (Uji Kemampuan Berbahasa Indonesia) tidak saja sebagai pengukuran untuk penguasaan bahasa Indonesia oleh kalangan warga Indonesia melainkan pada kalangan pekerja maupun pelajar asing yang masuk ke Indonesia berdampingan dengan TOEFL atau IELTS. Hasil UKBI juga dapat dipadang sebagai apresiasi dan penghargaan bagi warga asing ataupun warga keturunan asing yang berada di Indonesia sehingga mereka menjadi lebih bersemangat dan bangga dalam menggunakan bahasa Indonesia. Hal ini diharapkan mampu membantu untuk melindungi bahasa dan identitas nasional khususnya di kalangan warga keturunan asing.

\section{PENUTUP}

\section{Kesimpulan}

Dari hasil penelitian yang dilakukan, maka dapat diambil kesimpulan bahwa presentase jumlah campur kode yang terjadi dilihat dari hasil angket yang dibagikan yaitu, campur kode bentuk leksikal sebanyak $75 \%$, campur kode bentuk frasa sebanyak $8,3 \%$ dan campur kode bentuk klausa sebanyak 16,7\%. Hasil analisis data juga menemukan beberapa bentuk campur kode frasa dan kalusa yang berupa pengulangan serta idiom dalam bahasa Jepang.

Campur kode yang sering digunakan terjadi pada informan berumur berkisar 40 hingga 63 tahun. Hal ini menunjukkan bahwa warga keturunan Indonesia-Jepang masih sering mencampurkan antara bahasa Indonesia dan bahasa Jepang di dalam kehidupan sehari-hari.

Untuk mengurangi terjadinya campur kode di kalangan warga keturunan IndonesiaJepang tersebut, maka diperlukan suatu pemberdayaan bahasa Indonesia. Salah satu bentuk pemberdayaan tersebut adalah menanamkan rasa prestise (bangga) dan loyalitas terhadap penggunaan bahasa Indonesia di kalangan warga keturunan Jepang Indonesia. Dengan loyalitas itu, bahasa Indonesia akan diwariskan dari generasi ke generasi. Selain itu, menjadikan bahasa Indonesia menjadi bahasa pengantar di lingkungan warga keturunan IndonesiaJepang dan juga dalam upacara-upacara yang berhubungan dengan budaya.

Hal yang diperlukan adalah kiat pemberdayaan bahasa Indonesia di kalangan warga keturunan Indonesia-Jepang di kota Medan yaitu memberikan peluang dan kesempatan bagi pengguna dalam memberdayakan bahasa Indonesia secara kreatif dan inovatif.

Beberapa macam hal yang dapat digunakan dalam pemberdayaan bahasa Indonesia melalui pembudayaan bahasa, yaitu Pembudayaan Penggunaan Bahasa Indonesia yang Baik dan Benar, pembudayaan penggunaan bahasa Indonesia dengan percaya diri, pembu- 
dayaan penggunaan bahasa Indonesia yang efektif, pembudayaan penggunaan bahasa Indonesia yang loyal, pembudayaan bangga pada bahasa Indonesia

\section{Saran}

Di era globalisasi ini fenomena kontak bahasa tidak dapat dihindarkan. Oleh karena itu dampak dari kontak bahasa antara satu bahasa dengan bahasa lainnya tentu sangat banyak terjadi di dalam masyarakat. Kebanyakan dampak dari kontak bahasa adalah gangguan berbahasa. Gangguan berbahasa perlahanlahan akan menyebabkan pergeseran bahasa Indonesia hingga dikhawatirkan akan mempengaruhi eksistensi bahasa Indonesia itu sendiri. Karena itu penelitian dan kajian mengenai fenomena gangguan berbahasa sangatlah penting untuk terus dilakukan sebagai upaya untuk menemukan solusi atas permasalahan kebahasaan yang ada, serta memperkuat loyalitas dalam menggunakan bahasa Indonesia sebagai bahasa Nasional.

Campur kode adalah salah satu fenomena gangguan kebahasaan yang sering terjadi di masyarakat. Karena itu perlu dilakukan kajian lebih lanjut mengenai campur kode tidak hanya diantara bahasa Indonesia dengan bahasa Jepang, namun juga bahasa asing lainnya dalam kalangan masyarakat yang berbeda.

\section{DAFTAR PUSTAKA}

Fishman, J. 1972. Sosiolinguistic A brief Introduction, Massachusets : Newbury Hause Publisher, inc.

Halliday, M. A. K, \& Hasan, Ruqaiya. 1976. Cohesion in English. New York: : Longman.

Kridalaksana, Harimurti. 2001. Kamus Linguistik Edisi ketiga. Jakarta : PT. Gramedia Pustaka Utama.

Miles, Metthew B, A. Michael Huberman and Johnny Saldana. 2014. Qualitative Data Analysis, A Methods Sourcebook, Third Edition. Sage Publications, Inc.
Moeliono, Anton M. 1985. Pembinaan dan Pengembangan Bahasa: Ancangan Alternatif dalam Perencanaan Bahasa. Jakarta: Djambatan

Moleong, Lexy J. 2000. Metode Penelitian Kualitatif. Louisville. PT. Remaja Rosdakarya.

Sudaryanto. 1993. Metode dan Aneka Tehnik Analisis Bahasa ( Pengantar Penelitian Wahana Kebudayaan secara Linguistik). Yogyakarta: Duta Wacana University Press.

Suwito. 1983. Pengantar Awal Sosiolinguisti: Teori dan Problema. Surakarta: Henary cipta. 